\title{
$\begin{array}{lllllllllllllllll}\mathbf{R} & \mathbf{O} & \mathbf{Z} & \mathbf{P} & \mathbf{R} & \mathbf{A} & \mathbf{W} & \mathbf{Y} & \text { I } & \text { A } & \mathbf{R} & \mathbf{T} & \mathbf{Y} & \mathbf{K} & \mathbf{U} & \mathbf{L} & \mathbf{Y}\end{array}$
}

Prawo Kanoniczne

61(2018) nr 3

DOI:10.21697/pk.2018.61.3.01

KS. HENRYK STAWNIAK SDB

Wydział Prawa Kanonicznego

Uniwersytetu Kardynała Stefana Wyszyńskiego w Warszawie

\section{KLERYCKIE STOWARZYSZENIE WSPÓLNOTY EMMANUEL Z UPRAWNIENIEM INKARDYNACJI}

Treść: Wstęp. - 1. Troska o wszystkie Kościoły w kontekście inkardynacji. - 2. Czym są publiczne stowarzyszenie kleryckie? - 3. Początki wspólnoty Emmanuel i stan prawny stowarzyszenia kleryckiego. - 4. Wokół uprawnienia inkardynacji w 'ruchach kościelnych'. - Zakończenie.

\section{Wstęp}

Z Annuario Pontificio z 2010 roku wynikało ${ }^{1}$, że Stolica Apostolska poprzez Kongregację ds. Duchowieństwa udzieliła niektórym publicznym stowarzyszeniom wiernych przywileju inkardynowania należących do nich duchownych. Trudno było jednak wówczas dotrzeć do unormowań prawnych wymienionych tam publicznych kleryckich stowarzyszeń ${ }^{2}$. Aktualnie wymienia się pięć tego rodzaju stowarzyszeń. Są to: Wspólnota św. Marcina, erygowane w 2000 roku, Stowarzyszenie św. Jana-Maria Vianneya erygowane w 2002 roku, Dzieło Jezusa Najwyższego Kapłana erygowana w 2008 roku, Braterstwo Kapłanów Diecezjalnych Serca Jezusowego erygowane

\footnotetext{
${ }^{1}$ Por. Annuario Pontificio, Roma 2010, s. 1491, 1902; Codex Iuris Canonici, Kodeks Prawa Kanonicznego, Komentarz, edycja polska wydania hiszpańskiego pod red. P. Majera, Wolters Kluwer, Kraków 2011, [odtąd Komentarz...] s. 249.

${ }^{2}$ Por. H. StAwniak, Inkardynacja $w$ misji Kościoła w porządku prawnym Kościoła łacińskiego, Wydawnictwo UKSW, Warszawa 2013, s. 247.
} 
też w 2008 roku oraz Międzynarodowe Stowarzyszenie Kleryckie Wspólnoty Emmanuel erygowane 2017 roku33. Szczególne zainteresowanie budzi ta najnowsza wspólnota erygowana dekretem $\mathrm{z}$ dnia 15.08.2017 (prot. n. 20172741) Kongregacji ds. Duchowieństwa. Wspólnota Emmanuel ma bowiem interesującą historię, zmieniała swój status prawny i otrzymała prawo inkardynacji duchownych. Zwłaszcza ten ostatni aspekt będzie stanowił przedmiot dociekań, gdyż w rzeczywistości pokazuje on nową strukturę kościelną inkardynacji, która poszerza krąg instytucji mających takie uprawnienia. Istotne też będzie pokazanie misji duchownych w kontekście troski o cały Kościół. Zresztą ta ostatnia kwestia jest punktem wyjścia do właściwego rozumienia ewolucji instytucji inkardynacji. Wobec wielości i różnorodności 'ruchów kościelnych', które aktywnie włączają się w misję Kościoła, są źródłem nowych powołań kapłańskich i skutecznym narzędziem nowej ewangelizacji, nie można nie stawiać pytań w stosunku do instytucji inkardynacji. Powstaje bowiem zasadnicze pytanie: czy nie powinien każdy motus ecclesialis mieć uprawnień inkardynacyjnych, skoro ona jest nie tylko narzędziem posługi, lecz służy szeroko rozumianej ochronie prawnej duchownego i rozwojowi duchowemu? Inni zaś pytają: czy to nie jest deprecjonowanie instytucji skoro udziela się wielu osobom prawnym (stowarzyszeniom) prawa inkardynowania duchownych? Stowarzyszenie Kleryckie Wspólnoty Emmanuel jest wyjściem Kościoła naprzeciw potrzebom wiernych w duchu troski duchownych o wszystkie Kościoły i jest jednocześnie ciekawym przypadkiem rozwoju 'ruchu kościelnego' od prywatnego stowarzyszenia wiernych, przez publiczne stowarzyszenie wiernych Wspólnoty Emmanuel, do wyłonienia się w niej Międzynarodowego Stowarzyszenia Kleryckiego, na prawie papieskim, mającego uprawnienie inkardynacji.

\footnotetext{
${ }^{3}$ Por. Annuario Pontificio, Roma 2018, s. 1671, 1850-1851.
} 


\section{Troska o wszystkie Kościoły w kontekście inkardynacji ${ }^{4}$}

Natura Kościoła, jego uniwersalna misja, prawa wiernych do otrzymania darów słowa Bożego i sakramentów wpisują się w posługę biskupa i kapłana. Troska biskupa o powierzony Kościół partykularny była zawsze obecna w teologii i prawie kanonicznym. Natomiast troska o Kościół powszechny ${ }^{5}$ ujawnia się z całą mocą dopiero w nauce Soboru Watykańskiego II. Dokumentem w całości poświęconym zadaniom biskupa w Kościele jest Dekret Christus Dominus [DC]. Wspomniany Dekret w swojej treści uwzględnia i wylicza zadania biskupa wobec całego Kościoła, diecezji, wobec większej ilości kościołów. Wymowny jest tekst CD nr 6 mówiący o relacji biskupa do Kościoła powszechnego. Oto on:

„Biskupi, jako prawowici następcy Apostołów i członkowie kolegium biskupiego, niech zawsze będą świadomi swej wzajemnej łączności i niech okazują zatroskanie o wszystkie Kościoły, ponieważ każdy z nich wskutek Bożego ustanowienia i nakazu razem z pozostałymi biskupami jest odpowiedzialny za apostolską misję Kościoła. Niech się troszczą zwłaszcza o te regiony świata, w których słowo Boże nie było jeszcze głoszone albo w których, szczególnie z powodu małej liczby kapłanów, wierni narażeni są na niebezpieczeństwo odejścia od nakazów życia chrześcijańskiego, a nawet utraty samej wiary. (...) Niech dbają również o to, aby na ile to możliwe, niektórzy spośród ich kapłanów udawali się na wspomniane misje i do takich diecezji i podejmowali tam święte posługiwanie na stałe albo choćby na określony czas".

\footnotetext{
${ }^{4} \mathrm{~W}$ tym punkcie wykorzystano publikację wraz zamieszczoną tam literaturą: H. STAWNIAK, Inkardynacja..., dz. cyt., s. 140-158, 247.

${ }^{5}$ Troska o wszystkie Kościoły była już wzmiankowana w następujących dokumentach przed Soborem Watykańskim II: por. PIUs XII, Enciclica Fidei donum, AAS 49(1957), s. 237; BENEDy KT XV, List apostolski Maximum illud, AAS 11(1919), s. 440; PIUs XI, Enciclica Rerum Ecclesiae, AAS 18(1926), s. 68n.
} 
Przytoczony tekst soborowy wyraźnie mówi o obowiązku troski o wszystkie Kościoły ze strony biskupa, jako następcy Apostołów i członka kolegium biskupiego. Każdy biskup z ustanowienia Bożego i nakazu razem z innymi biskupami jest odpowiedzialny za apostolską misję Kościoła, która realizuje się przez głoszenie słowa Bożego i przez sakramenty. Troska biskupa o Kościół powszechny wywodzi się z natury sakry biskupiej i z kolegialności biskupów. Potrójne zadanie biskupa, to jest nauczanie, uświęcanie i rządzenie, przekazywane jest biskupowi przez sakrę. Obowiązek troski o Kościól, mający podstawy w sakrze biskupiej, jest obowiązkiem pochodzącym z prawa Bożego. Sakra biskupia daje udział w potrójnym zadaniu w sposób ontyczny. To sakramentalne wyposażenie, by stało się konkretną władzą, wymaga określenia społeczno-prawnego ze strony najwyższej władzy kościelnej ${ }^{6}$. Odpowiedzialność biskupów za realizację misji Kościoła wobec wszystkich ludów jest solidarna. Jest ona wprawdzie wyrazem znanej i od początku Kościoła praktykowanej zasady 'sollicitudo omnium ecclesiarum', ale właśnie ta zasada otrzymała w dokumentach soborowych pełniejsze naświetlenie i uzasadnienie. Konsekwencją tej doktryny jest też uświadomienie biskupom potrzeby wysyłania swoich kapłanów na czas określony lub na stałe do regionów lub obszarów, które oczekują podjęcia posługi słowa Bożego i sakramentów. Ponieważ troska o cały Kościół płynie z sakry biskupiej, spoczywa więc na każdym kto ją otrzymał. Troska biskupa o wszystkie Kościoły łączy się bezpośrednio z potrzebą dokonania ekskardynacji duchownego z własnej diecezji lub też dokonania czasowego przydzielenia duchownego (addictio).

Sobór Watykański II nakreślił nie tylko nowe ujęcie posługi biskupa, ale też dał nowe ujęcie kapłaństwa, pokazał jego prawdziwą naturę i zadania. Nowość soborowego ujęcia jest widoczna, gdy się

\footnotetext{
${ }^{6}$ Por. W. Bertrams, De differentia inter sacerdotium episcoporum et presbyterorum, Periodica 59(1970), s. 197-199; S. NAGy, Nauka o episkopacie w Konstytucji „Lumen gentium”, w: Pastori et mistero, Lublin 1966, s. 152; F. DzIUBA, Kapłan w służbie partykularnego i powszechnego Kościoła, Prawo Kanoniczne 47(2004) nr 1-2, s. 4-8.
} 
je porówna z ujęciem teologii przedsoborowej, w której kapłaństwo rozpatrywano wyłącznie w relacji do uświęcenia i akcentowania czynności kultowych - Eucharystia i Pokuta7. Sobór Watykański II rozpatruje kapłaństwo jako udział w misji apostolskiej Kościoła, czyli zadaniach nauczania, uświęcania i kierowania. W ten sposób kapłani uczestniczą razem z biskupami w tej samej misji Kościoła. Kapłani i biskupi uczestniczą również w tym samym kapłaństwie Chrystusa ${ }^{8}$.

Wymowną i bogatą treść w tym względzie zawiera dekret Presbiterorum ordinis [PO] nr 10:

Dar duchowy, który prezbiterzy otrzymali przez święcenia, przygotowuje ich nie do ograniczonego i zacieśnionego posłannictwa, lecz do najstarszej i powszechnej misji zbawienia 'aż po krańce ziemi' (Dz 1,8), albowiem kapłańska posługa uczestniczy w powszechnym zasięgu posłannictwa powierzonego przez Chrystusa Apostołom. Chrystusowe kapłaństwo, którego prezbiterzy prawdziwie stali się uczestnikami, kierowane jest oczywiście do wszystkich narodów i czasów i nie jest skrępowane żadnymi ograniczeniami krwi, rasy czy epoki, jak to już w tajemniczy sposób wyobraża osoba Melchizedeka. Niech więc prezbiterzy pamiętają o tym, iż winna im leżeć na sercu troska o wszystkie Kościoły.

Zatem dar duchowy otrzymany w święceniach prezbiteratu uzdalnia ich do podjęcia troski o wszystkie Kościoły, a uczestnictwo w Chrystusowym kapłaństwie jest ukierunkowaniem na wszystkie narody. Czyli możemy mówić, że troska o wszystkie Kościoły prezbiterów wynika zarówno z natury kapłaństwa, jak i z faktu bycia współpracownikiem biskupa. Sobór, ukazując uniwersalny charakter kapłaństwa, ustawił je na płaszczyźnie ogólnokościelnej. Takie ustawienie jest wielkim novum w stosunku do norm CIC z 1917 roku,

${ }^{7}$ B. Przybylski, Wprowadzenie do Dekretu o posłudze i życiu kapłanów, w: Sobór Watykański II, Poznań 2002, s. 478.

${ }^{8}$ Por. LG nr 19 i 21; CD nr 28, PO nr 7; F. Dziuba, Kapłan..., dz. cyt., s. 8-11. 
gdzie nie tylko posługa prezbitera, ale i urząd biskupa miał wymiary 'diecezjalne'.

Troska o wszystkie Kościoły ma ścisły związek z instytucją inkardynacji. Dekret PO, tak istotny w ukazaniu pogłębionej nauki o kapłaństwie, nawiązuje też wprost do instytucji inkardynacji. Ojcowie soborowi znając walory i ograniczenia tej instytucji, dostrzegali potrzebę innego jej ujęcia. We wspomnianym dekrecie czytamy: „Dlatego normy dotyczące inkardynacji i ekskardynacji trzeba w taki sposób poprawić, aby ten prastary przepis, pozostając nienaruszony, lepiej odpowiadał jednak dzisiejszym potrzebom duszpasterskim" . Bardzo jasno jest wyrażona wola pozostawienia tej instytucji w swojej istocie, natomiast pragnieniem było takie jej przekształcenie, aby sprzyjała zaspokojeniu nowych potrzeb duszpasterskich i ułatwiała podjęcie wyzwań współczesności. Skoro misja biskupów i kapłanów dotyczy troski o wszystkie Kościoły, to konsekwentnie w tym kierunku winno iść przekształcenie instytucji inkardynacji, by ją umożliwiać.

Ten sam dokument wskazuje możliwe formy przekształcenia tych prastarych przepisów sprowadzających zwykle inkardynację tylko do diecezji lub zakonu. Aktualnie „należy ułatwiać nie tylko właściwe rozmieszczenie prezbiterów, ale także trzeba zorganizować specjalne dzieła duszpasterskie dla różnych grup społecznych, w niejednym regionie lub narodzie czy też w każdej części świata. W tym więc celu można z pożytkiem utworzyć seminaria międzynarodowe, specjalne diecezje lub prałatury personalne i inne tego rodzaju instytucje, do których dla wspólnego dobra Kościoła można przeznaczać lub inkardynować prezbiterów w ten sposób, który zostanie określony dla każdego z tych przedsięwzięć i zawsze z zachowaniem praw miejscowych ordynariuszy"10. Zatem dekret soborowy wskazuje możliwość przekształcenia relacji inkardynacji poprzez nowe struktury kościelne, które mogłyby mieć prawo inkardynowania. Wymienia prałaturę personalną jako konkretną strukturę kościelną, a także

\footnotetext{
${ }^{9} \mathrm{PO}, \mathrm{nr} 10 / 2$.

${ }^{10} \mathrm{PO}, \mathrm{nr} 10 / 2$.
} 
specjalne diecezje i inne tego rodzaju instytucje, które mogą podjąć nowe wyzwania duszpasterskie. W tej optyce misja duszpasterska staje się siłą inspirującą i przekształcającą instytucję inkardynacji. Poszerzone okręgi ewangelizowania narodów znajdują dopełnienie przez soborowe wskazanie możliwości przeznaczania czasowego prezbiterów do tych nowych przedsięwzięć lub inkardynacji do nich. Zwraca więc uwagę możliwość czasowej przynależności [addictio] do nowych struktur, przy zachowaniu inkardynacji we własnej jednostce. Te ogólne wskazania znajdą wkrótce ukonkretnienie w motu proprio Ecclesiae sanctae z 1966 roku $^{11}$.

Należy także zauważyć zachętę soborową do prezbiterów i biskupów o włączenie się w nowe posługi duszpasterskie. „Dlatego prezbiterzy tych diecezji, które są obdarzone większą liczbą powołań kapłańskich, niech chętnie okazują, za pozwoleniem lub przy zachęcie własnego ordynariusza, gotowość pełnienia posługi w krajach, na miejscach lub w dziełach, którym brakuje duchowieństwa"12.

Aktualny Kodeks prawa kanonicznego wylicza w kan. 265 następujące struktury inkardynacyjne: Kościoły partykularne i prałatury personalne, jak również instytuty życia konsekrowanego [instytuty zakonne i świeckie] i stowarzyszenia życia apostolskiego. W tym kanonie prawodawca w sposób widoczny rozróżnia dwie grupy instytucji upoważnionych do inkardynowania. Wynika to z dysjunktywnej konstrukcji „aut - aut” (albo - albo) w przeciwieństwie do konstrukcji vel (lub), łączącej podgrupy. Mamy więc z jednej strony Kościoły partykularne i prałatury personalne, a z drugiej wspólnoty związane z życiem konsekrowanym i życiem apostolskim.

Nie należy przy tym zapominać o tym, że wyliczenie w kan. 265 jest już nieaktualne z kilku powodów. Najpierw Jan Paweł II dnia 21.04.1986 roku wydał konstytucję apostolska Spirituali militum curae mocą której powołał ordynariaty wojskowe, które stały się nową

\footnotetext{
${ }^{11}$ Paulus VI, Litterae apostolicae motu proprio datae Ecclesiae Sanctae, 6.08.1966, AAS 58(1966), s. 757-758.

${ }^{12} \mathrm{PO}, \mathrm{nr} 10 / 2$.
} 
instytucją upoważnioną do inkardynowania (art. VI $\$ \$ 3-4)^{13}$. Następnie w dniu 18.01.2002 roku Kongregacja ds. Biskupów, na mocy specjalnego mandatu Ojca Świętego Jana Pawła II, ogłosiła dekret Animarum bonum erekcyjny Administratury apostolskiej personalnej Świętego Jana Marii Vianney ${ }^{14}$. Innym zjawiskiem, które zrodziło życie, jest przejście duchownych anglikańskich na katolicyzm. Dnia 4 listopada 2009 r. została wydana Konstytucja apostolska papieża Benedykta XVI Anglicanorum coetibus ${ }^{15}$ pozwalająca na tworzenie ordynariatów personalnych dla anglikanów nawiązujących pełną komunię z Kościołem katolickim. Następnie, w tym samym dniu, promulgowano Normy ${ }^{16}$ uzupełniające do wymienionej Konstytucji apostolskiej ${ }^{17}$. Ordynariatów personalnych nie da się zaliczyć do żadnej instytucji wymienionej w kanonie 265. Ordynariat personalny dla anglikanów nie jest ani kościołem partykularnym, ani prałaturą personalną, ani instytutem życia konsekrowanego, ani nie jest też stowarzyszeniem. W ten sposób podjęta w kan. 265 próba uogólniającego wyliczenia i typizacji jest nie tylko nieadekwatna i niepełna, ale także jest nieudana, jak ją określił jeden $\mathrm{z}$ kanonistów ${ }^{18}$. Z dekretu Kongregacji ds. Duchowieństwa z dnia 15.08.2017 wynika, że Stowarzyszenie Kleryckie jest publicznym stowarzyszeniem Wspólnoty Emmanuel, na prawie papieskim, osobą prawną z uprawnieniem inkardynowania duchownych. Nowa więc struktura inkardynacji rodzi pytanie o istotę tych stowarzyszeń.

${ }^{13}$ AAS 78(1986) 481-486, tekst polski w: Ustrój hierarchiczny Kościoła. Wybór Źródeł, red. i oprac. W. Kacprzyk, M. Sitarz, Lublin 2006, s. 211-216, tutaj s. 214.

${ }^{14}$ AAS 94(2002), s. 305-308.

${ }^{15}$ Por. AAS 101(2009), s. 985-990.

${ }^{16}$ Por. Normy Uzupełniajace do Konstytucji apostolskiej Anglicanorum coetibus, Wiadomości KAI z 22 XI 2009, s. 28-29.

${ }^{17}$ Por. H. Stawniak, Celibat diakonów i prezbiterów $w$ dyscyplinie Kościoła łacińskiego, w: Kapłaństwo posługi, red. A. Skorupa SDS, A. Słowikowska, Lublin 2012, s. $41-44$.

18 „Die in c. 265 versuchte generalisierende Aufzählung und Typisierung ist damit nicht nur überholt und unvollständig; sie mus sals ingesamt misslungen angesehen werden". H. Schmitz, Die Inkardadinazione im Hinblick auf die konsoziativen Strukturen, St. Ottilien 1989, s. 704. 


\section{Czym są publiczne stowarzyszenia kleryckie?}

W odpowiedzi na to pytanie należy odnieść się do kan. 302 KPK, który na ten temat stanowi: „Kleryckimi stowarzyszeniami wiernych są nazwane te, które są kierowane przez duchownych, podejmują wykonywanie święceń oraz jako takie są uznawane przez kompetentną władzę".

W komentarzu hiszpańskim ${ }^{19}$ do tego kanonu zwraca się uwagę na to, że aby zakwalifikować stowarzyszenie jako kleryckie, powinno ono spełniać jednocześnie trzy warunki: 1. Stowarzyszenie musi być kierowane przez duchownych. 2. Celem stowarzyszenia musi być wykonywanie święceń w znaczeniu kapłaństwa ministerialnego oraz 3. Stowarzyszenie to musi być erygowane przez kompetentną władzę kościelną - stąd ich charakter publiczny. Co do wykonywania święceń w znaczeniu ministerialnym, to należy zauważyć, że komentowany przepis nie zawiera wprost takiej dyspozycji. Natomiast, jak się wydaje, wykonywanie święceń powinno przybrać jedną ze szczególnych form posługiwania, na przykład na terenach misyjnych lub w odniesieniu do kategorii wiernych, którzy potrzebują szczególnej opieki duszpasterskiej (emigranci, określone grupy narodowościowe itp.). W tej materii ważne jest dopowiedzenie komentarza, że w ostatnim projekcie obecnego Kodeksu ${ }^{20}$ był przepis umieszczony jako następny po obecnym kan. 315, umożliwiający tworzenie stowarzyszeń mających prawo inkardynowania duchownych. Chciano w ten sposób stworzyć możliwość powoływania stowarzyszeń misyjnych dla duchowieństwa niezakonnego, które z braku innych rozwiązań prawnych zmuszone były przybrać formę stowarzyszeń życia wspólnego bez ślubów, ad instar religiosorum. Przy ostatniej rewizji tego projektu wspomniany przepis został zniesiony, gdyż uznano, że taką możliwość daje instytucja stowarzyszeń życia apostolskiego. W rezultacie w obecnym kodeksie pozostał przepis zezwalający na tworzenie stowarzyszeń kleryckich, pozbawiony jednak kanonu, wokół którego skupiła się

\footnotetext{
${ }^{19}$ Por. Komentarz..., dz. cyt., s. 283-284.

${ }^{20}$ Por. Communicationes 12(1980), s. 109-112.
} 
reszta rozstrzygnięć normatywnych ${ }^{21}$. Zatem usunięcie z projektu z 1980 roku normy pozwalającej na szczegółowe rozwiązania było błędem, skoro te sprawy rozwiązuje się poprzez specjalne upoważnienia kompetentne kongregacji na mocy specjalnych uprawnień otrzymanych od papieża ${ }^{22}$. Z kolei 3. warunek, czyli że stowarzyszenia te musi erygować kompetentna władza kościelna, ma związek z kan. 312, który wyjaśnia, że dla stowarzyszeń na poziomie powszechnym oraz międzynarodowym kompetentna jest Stolica Apostolska, dla krajowych jest konferencja episkopatu i dla diecezjalnych stowarzyszeń biskup diecezjalny. Natomiast określenie kleryckie stowarzyszenie, jak czytamy we wzmiankowanym komentarzu, oznacza ich szczególną kwalifikację prawną, która odnosi się nie tylko do osób kierujących stowarzyszeniem i do koniecznego w tym wypadku aktu ustanowienia stowarzyszenia jako kleryckiego przez władzę kościelną, lecz także do tego wyróżnika, jakim jest wykonywanie przez członków stowarzyszenia posługi święceń ${ }^{23}$.

Stowarzyszenia kleryckie oparte na kan. 302 różnią się zdecydowanie od stowarzyszeń kapłanów opartych na naturalnym prawie duchownych do stowarzyszania się w myśl kan. 278. Stąd też stowarzyszenia zrzeszające jedynie duchownych, którego celem byłaby troska o rozwój duchowości jego członków, spełniających, pod władzą własnego ordynariusza, kapłańską posługę, z prawnego punktu widzenia jest kwalifikowane jako zwykłe stowarzyszenie wiernych i może mieć charakter zarówno publiczny, jak i prywatny (por. kan.

\footnotetext{
${ }^{21}$ Por. Komentarz..., dz. cyt. s. 284; M. Delgado Galindo, Movimenti..., dz. cyt., s. 658; J. L. Gutiérrez, <sub can. 302>, w: J.I. Arrieta (Ed), Codice di Diritto Canonico e leggi complemantari: commento, Roma 2015, wyd. 5, s. 259-260.

${ }^{22}$ Warto wspomnieć, że papież Benedykt XVI w dniu 11.01.2008 udzielił Kongregacji ds. Duchowieństwa przywileju papieskiego udzielania niektórym stowarzyszeniom publicznym kleryckim uprawnienia do inkardynowania duchownych, którzy o to proszą. Z kolei 29.05.2017 roku papież Franciszek potwierdził ten przywilej dla Kongregacji ds. Duchowieństwa.

${ }^{23}$ Por. Komentarz..., dz. cyt., s. 284.
} 
$278 \mathrm{KPK})^{24}$. W tym kontekście warto podkreślić, że prawu do stowarzyszania się nie stoi na przeszkodzie przynależność kapłana do ordo presbyterorum i - przez prawne więzy inkardynacji - do prezbiterium. Motywy te nie są wystarczające do zanegowania takiego prawa, przede wszystkim $z$ dwóch powodów. Po pierwsze, prezbiterium diecezji nie jest stowarzyszeniem duchownych, lecz formą organizacyjną sprawowanej posługi, a po drugie, prezbiterzy poza stosunkiem zależności od biskupa, wynikającą z więzów sakramentalnych (święcenia) i prawnych (inkardynacja), posiadają zgodną z prawem autonomię oraz wolność przysługującą każdej osobie. Z nich wynika prawo do stowarzyszania się, zarówno w stowarzyszeniach świeckich, jak też istniejących w Kościele ${ }^{25}$. Stowarzyszenia publiczne kleryckie, którym przyznano możliwość inkardynowania duchownych niedawno, wpisują się w optykę misji troski o wszystkie Kościoły. Należy przy tym zauważyć, że uprawnienie inkardynacji przez kompetentnych przełożonych do Instytutów Zakonnych, do Stowarzyszeń Życia Apostolskiego i do Instytutów Świeckich oraz Stowarzyszeń Kleryckich nie należy do praw istotowo właściwych tym strukturom, ale jest ono wtórne, bowiem dopiero z czasem i nawet niedawno pojawiła się możliwość inkardynacji do tych struktur kościelnych, jako rozwiązanie sprzyjające posłudze duszpasterskiej. Nowe możliwości inkardynacyjne, także w odniesieniu do wspólnot stowarzyszeniowych, można nazwać znaczącą innowacją ${ }^{26}$.

\section{Początki Wspólnoty Emmanuel i stan prawny stowarzyszenia kleryckiego}

Założyciel Wspólnoty Emmanuel, Pierre Goursat (1914-1991), to człowiek, który doświadczył nawrócenia i wylania Ducha Świętego. Odkrył w sobie szczególne umiłowanie Serca Jezusowego, adoracji

\footnotetext{
${ }^{24}$ Por. M. Delgado Galindo, Movimenti..., dz. cyt., s. 659; Komentarz..., dz. cyt., s. 284.

${ }^{25}$ Por. Komentarz..., dz. cyt., s. 261.

${ }^{26}$ Por. J. Steinbach, Das Verhältnis von «Inkarination" und «Urcharisma» in den kirchlichen Lebensverbänden, Periodica de re canonica 85(1996), s. 280-282.
} 
eucharystycznej, wreszcie powołania do życia w celibacie i do apostolstwa świeckiego. W roku 1971 spotyka Martine Laffitte-Catta, młodą pielęgniarkę o wielkich duchowych aspiracjach, animatorkę małej szkoły modlitwy w Paryżu. Potem Pierre dowiedział się o początkach Odnowy Charyzmatycznej w USA i Kanadzie. Te dwa wydarzenia i dwudniowe spotkanie w lutym 1972 roku w domu rekolekcyjnym w Troussures wraz z wylaniem Ducha Świętego na nich dało początek grupie modlitewnej. Potem powstają liczne grupy modlitewne o różnym zaawansowaniu duchowym i aby je jednoczyć, postanowiono, że wspólną nazwą grup ma być Emmanuel ${ }^{27}$, to jest „Bóg z nami”. Moderatorem grup został Pierre Goutsat i pełnił tę funkcję do roku 1985. Grupy modlitewne określone nazwą Emmanuel nie były jednak jeszcze wspólnotą. Nic więc dziwnego, że wiosną 1973 roku Pierre i Martine podejmują decyzję, aby razem służyć Panu i ewangelizować, i jeśli to możliwe, $\mathrm{w}$ formie stowarzyszenia ${ }^{28}$. Dostrzegają przy tym potrzebę włączenia połączonych grup w struktury Kościoła i dlatego podejmują dialogi z hierarchami Paryża, Brukseli, Nicei i Pary-le-Monial. Ze strony Kościoła było zainteresowanie, ale nie było oficjalnej aprobaty.

W roku 1974 tworzy się mała grupa osób na czele z Pierre, którzy w odosobnieniu podejmują styl życia ukierunkowanego na modlitwę i pogłębienie życia duchowego. Ta idea dała początek potem wspólnocie Fraternité de Jésus - Fraternia Jezusa i stała się pierwszym 'stałym domkiem’ nieformalnej jeszcze Wspólnoty Emmanuel. W roku 1975 zaangażowali się oni mocno w przygotowanie 1000 rodaków do spotkania z papieżem Pawłem VI w Rzymie, zaś w lipcu tego roku przeprowadzono w Paray-le-Monial pierwsze, tygodniowe sesje letnie

${ }^{27}$ „Oto Dziewica pocznie i porodzi Syna, któremu nadadzą imię Emmanuel, to znaczy Bóg z nami” Mt 1,23. Pismo Święte Starego i Nowego Testamentu, Poznań Warszawa 1990.

${ }^{28}$ Por. B. Peyrous, H.M. Catta, Le feu et l'espérance. Pierre Goursat Fondater de la Communauté de l"Emmanuel [dalej FE], Paris 1995, ss. 17- 57; por. też P. BARYLAK, Udział prywatnych stowarzyszeń wiernych w posłannictwie Kościoła na przykładzie Wspólnoty Emmanuel i Wspólnoty Błogosławieństw. Studium teologiczno-prawne, [mps praca magisterska pod kierunkiem ks. H. Stawniaka], Warszawa 2000, s. 46-52. 
po 600 osób. Aspiracje duchowe Goutsat oraz orędzie z Paray-le-Monial bardzo szybko spotkały się ze sobą. Kult Serca Jezusa zaczął również zajmować ważne miejsce we wspólnotach ${ }^{29}$. Dnia 18.06.1977 roku miały miejsce pierwsze przyjęcia w formie zaangażowania do wspólnoty. Około 50 osób zobowiązało się, jedna po drugiej, przed Najświętszym Sakramentem, do życia modlitwy, służby i ewangelizacji ${ }^{30}$. W tym samym czasie inne 50 osób wypowiedziało swoją konsekrację jako członkowie Fraterni Jezusa. Zaczęły powstawać nowe domy w różnych regionach Francji i Europy, potem także na innych kontynentach.

Wprawdzie od roku 1974 starano się o uzyskanie statusu prawnego Emmanuela i Fraterni Jezusa w Kościele katolickim, to sprawy te szły opornie, również ze względu na prace nad nowym kodeksem. O. Jean Passicos, dziekan Fakultetu Prawa Kanonicznego w Paryżu, proponował wypracować 'wyważoną formułę, (solution équilibrée), która łączyłaby zarówno normalne życie wiernych świeckich, jak i aspekt wspólnotowy. Chodziło o taki statut, który jednoczyłby tym samym duchem uświęcenia i ewangelizacji przedstawicieli najrozmaitszych stanów $^{31}$. Pierwszy statut Fraterni Jezusa został zatwierdzony w dniu 29.06.1980 r. przez ordynariusza diecezji Nanterre, bp. Delarue, na okres 2 lat ad experimentum. W tym samym czasie Goutsat podjął rozmowy z nowym ordynariuszem Paryża z abp. Lustiger. W dniu 8.12.1982 r. wymieniony kardynał zatwierdził statuty dwu różnych stowarzyszeń wiernych: Wspólnotę Emmanuel dla wiernych świeckich oraz Fraternię Misyjną Serca Jezusowego dla kapłanów i kleryków, określając ich naturę jak pobożne związki (piae uniones). Podobnie zatwierdzili wymienione wspólnoty abp Marsylii, abp Lionu i diecezji Aix-en-Provence ${ }^{32}$.

\footnotetext{
${ }^{29}$ Por. M. Delgado Galindo, Movimenti..., dz. cyt., s. 652.

${ }^{30}$ Por. F. LenoIr, Nowe wspólnoty, wyd. polskie, tłumaczył K. Szczerba, Warszawa 1993, s. 99.

${ }^{31}$ Por. FE, s. 178.

${ }^{32}$ Por. FE, ss. 179-181.
} 
Pierre Goutsat nie był zadowolony ze statutów, gdyż 'kapłani i świeccy nie mieli tego samego statutu. Było to czymś niezgodnym z naturą Emmanuela. (...) Uważał, że tendencja klerykalizmu, była do uniknięcia, jeśli kapłani byliby stowarzyszeni ze świeckimi' ${ }^{33}$. Już po promulgacji nowego kodeksu, w roku 1985 kard. Lustiger zatwierdza Wspólnotę Emmanuel jako prywatne stowarzyszenie wiernych, w które angażować się mogą duchowni, małżeństwa, celibatariusze i osoby konsekrowane. Taki status też otrzymała Fraternia Jezusa. Potem inni hierarchowie kanonicznie zatwierdzali wspólnoty. Wreszcie dnia 9.12.1992 roku Moderator generalny Wspólnoty Emmanuel i Fraterni Jezusa, Gerar Arbola, następca Goutsata, przyjął z rąk kard. Pironio, Przewodniczącego Papieskiej Rady ds. Świeckich, dekret uznający Wspólnotę Emmanuel oraz Fraternię Jezusa jako powszechne prywatne stowarzyszenia wiernych na prawie papieskim, cieszące się osobowością prawną według norm określonych w kann. 298-311 i 321-329 KPK, oraz zatwierdzający ich statuty ad experimentum na 5 lat $^{34}$, potem miało ostateczne potwierdzenie w 1998 roku. Zatem od roku 1992 Wspólnota i Fraternia miały jeden statut i wspólnego moderatora. Ich charyzma i cel sprowadzały się do adoracji Eucharystii, do służby na rzecz ubogich i potrzebujących oraz ewangelizacji świata ${ }^{35}$.

Do Wspólnoty Emmanuel mogli należeć: 1) osoby ochrzczone i bierzmowane w Kościele katolickim, pełnoletnie według prawa kanonicznego i państwowego; 2) ochrzczeni niekatolicy uczestniczący jako bracia stowarzyszeni; 3) osoby przygotowujące się do sakramentu chrztu świętego mogły być dopuszczone do okresu probacji. Natomiast Fraternię Jezusa mogli jedynie stanowić niektórzy katolicy - członkowie Wspólnoty Emmanuel, rozeznający w sobie wezwanie bardziej radykalnego ofiarowania się oraz katolicy nie będący

\footnotetext{
${ }^{33}$ FE, s. $180-181$.

${ }^{34}$ Por. Status de la Communauté de l'Emmanuel et de la Fraternité de Jésus [odtąd SEF], Neuilly 1992, s. 3; P. Barylak, Udział..., dz. cyt., s. 52-59; M. Delgado Galindo, Movimenti..., dz. cyt., s. 653.

${ }^{35}$ Por. M. Delgado Galindo, Movimenti..., dz. cyt., s. 652.
} 
wprawdzie członkami Wspólnoty Emmanuel lecz zaangażowani już we wspólnotach żyjących podobnym duchem. Według stanu życia członkami Emmanuel i Fraterni byli: małżonkowie i celibatariusze, mężczyźni i kobiety żyjący w celibacie dla Królestwa niebieskiego, diakoni stali, kapłani, diakoni przygotowujący się do kapłaństwa, alumni, zakonnice i zakonnicy. Jednocześnie statuty zastrzegały, że zaangażowanie duchownych diecezjalnych we Wspólnocie lub Fraterni warunkuje pisemna zgoda ordynariusza miejsca, podobną zgodę swoich przełożonych wyższych winni otrzymać członkowie instytutów życia konsekrowanego i stowarzyszeń życia apostolskiego ${ }^{36}$. Fraternia w statucie jawi się jako stowarzyszenie radykalniejsze, dar siebie przez konsekrację ${ }^{37}$, zaangażowane na rzecz wierności Kościołowi oraz dyspozycyjności na rzecz misyjnej działalności ${ }^{38}$. Duchowni byli inkardynowani do diecezji, zaś duchowni życia konsekrowanego do wspólnot lub diecezji. Obowiązki takich duchownych określały umowy za porozumieniem ordynariusza i moderatora - przez szacunkową proporcję: jedna trzecia część czasu i posługi dla Wspólnoty, dwie trzecie dla diecezji. Ponadto kapłani i diakoni powinni tworzyć wspólnotę któregoś z 'domków’39. Okazało się, że charyzmat adoracji, współczucia i ewangelizacji dany założycielowi - Pierre’owi Goursat nie tylko został przyjęty w życiu setek, a potem tysięcy Francuzów, lecz przekraczając granice dziesiątki krajów europejskich, dotknął również innych kontynentów ${ }^{40}$. Rozwój Wspólnot i zaangażowanie członków sprawiło, że Papieska Rada ds. Świeckich dekretem z dnia 20.06.2009 roku przekształciła prywatne stowarzyszenie Wspólnoty Emmanuel w stowarzyszenie publiczne międzynarodowe wiernych, które jest taką figurą prawną aktualnie ${ }^{41}$.

\footnotetext{
${ }^{36}$ Por. SEF nr 5,6, 7, 8, 9,12.

${ }^{37}$ Statuty wyjaśniają, że chodzi tu najogólniej o konsekrację wypływającą z łaski chrztu świętego, jak to przedstawia konstytucja Lumen gentium 10.

${ }^{38}$ Por. SEF, Wprowadzenie IIb.

${ }^{39}$ Por. SEF, nr 28.

${ }^{40}$ Por. P. BARYlak, Udział..., dz. cyt., s. 77-78.

${ }^{41}$ https://www.emmanuel.info.pl/wp-content/uploads/2018/10/2018-pl-statut-wsplnoty-emmanuel-i-bractwa-jezusowego-fina.pdf [dostęp 1.12.2018]
} 
Jak wzmiankowano we wstępie opracowania, Kongregacja ds. Duchowieństwa 15.08.2017 roku erygowała w ramach Wspólnoty Emmanuel Stowarzyszenie kleryckie międzynarodowe publiczne w myśl kan. 302 i $312 \$ 1,1^{\circ} \mathrm{KPK}$. Ma ono uprawnienie inkardynacji, zachowując przy tym charakter stowarzyszeniowy. Członkowie Stowarzyszenia kleryckiego są członkami Wspólnoty albo Fraterni Jezusa. Kandydaci do kapłaństwa nie są w sensie ścisłym członkami Stowarzyszenia kleryckiego. Oni tylko uczestniczą w prawach i obowiązkach związanych $\mathrm{z}$ formacją $\mathrm{w}$ drodze do posługi diakonatu. Charyzmat Wspólnoty Emmanuel oparty na adoracji Eucharystii, na naśladowaniu Chrystusa w posłudze ubogim, chorym, emigrantom oraz na głoszeniu Ewangelii powoduje, że istnieje głęboka więź między kapłaństwem powszechnym i ministerialnym przeżywając swój stan życia. Duchowni i pozostali członkowie Wspólnoty tworzą grupę misyjną w służbie Kościołowi i są dyspozycyjni i mobilni we współpracy z biskupami. Członkowie Stowarzyszenia kleryckiego prowadzą zwykle życie we wspólnocie dla zachowania dyscypliny kościelnej w wierności Kościołowi i dla rozwoju ich życia duchowego. Stąd duchowni stowarzyszenia żyją w 'domkach', które są wyposażone w rzeczy konieczne do ich posługi. Stowarzyszenie ma także własne Ratio formacji, ale także jest wypracowywany regulamin wewnętrzny, który koresponduje z Ratio każdego kraju. Oba dokumenty są zatwierdzane przez Kongregację ds. Duchowieństwa. Stowarzyszenie kleryckie ma swoją siedzibę we Francji, w Neuilly-sur-Seine, graniczącym z Paryżem ${ }^{42}$.

Zgodnie ze statutem Stowarzyszenia kleryckiego jego członkami są: 1) kapłani inkardynowani do stowarzyszenia lub duchowni diecezji, którzy mają umowy potwierdzone przez biskupa i Odpowiedzialnego w stowarzyszeniu; 2) diakoni, którzy się przygotowują do kapłaństwa, inkardynowani do kleryckiego Stowarzyszenia lub mają umowę podpisaną przez biskupa i Odpowiedzialnego ze stowarzyszenia; 3) diakoni stali (żonaci lub celibatariusze) inkardynowania do

\footnotetext{
${ }^{42}$ Por. http://emanuel.info/actualites/creation-association-clericale/ Statuto: Il preambolo, artt. 1-6; M. Delgado Galindo, Movimenti..., dz. cyt., s. 661-662.
} 
stowarzyszenia lub mający umowę podpisaną przez biskupa i Odpowiedzialnego ze stowarzyszenia. Wszyscy oni mają prawa i obowiązki odpowiednie do miejsca inkardynacji. Duchowni diecezjalni stowarzyszeni we Wspólnocie są inkorporowani albo do Wspólnoty, albo do Fraterni Jezusa, zgodnie z umowami zawartymi przez biskupa z Odpowiedzialnym za duchownych i w zgodzie z Moderatorem generalnym Wspólnoty Emmanuel. Z kolei kandydaci do kapłaństwa i diakoni stali mają tylko czasowe więzy ze Stowarzyszeniem kleryckim. Natomiast ewentualna inkorporacja definitywna kandydatów do kapłaństwa diakonów stałych dokonuje się na prośbę zainteresowanych przed diakonatem. Przełożony (Odpowiedzialny) wspólnoty kleryckiej ma prerogatywy ordynariusza i zgodnie z prawem posiada uprawnienie promowania do święceń kandydatów, którzy pragnę być inkardynowani do stowarzyszenia. W statutach podkreśla się, że nie ma dwóch klas duchownych, to jest tych inkardynowanych do Wspólnoty i tych inkardynowanych do diecezji. Są to bowiem tylko dwa sposoby realizacji kapłaństwa w posłudze ministerialnej ${ }^{43}$.

Posłannictwo i zaangażowanie duchownych stowarzyszonych zależy od tego, jakie zadania im powierzy biskup w porozumieniu z Odpowiedzialnym i Moderatorem generalnym Wspólnoty Emmanuela. Zadania powierzone diakonom stałym winny korespondować z zadaniami względem rodziny. Z kolei duchowni inkardynowani do Wspólnoty zwykle podejmują większe wezwania niż duchowni inkardynowani do diecezji. Misja kanoniczna duchownych inkardynowanych do Stowarzyszenia kleryckiego jest przedmiotem listu posłuszeństwa danego przez Odpowiedzialnego za posługę ministerialną wyświęconych. Wszelkie spory co do posłannictwa są rozstrzygane $\mathrm{w}$ dialogu z zainteresowanymi stronami, ostatecznie zaś przez aktualną Radę ds. Świeckich, Rodziny i Życia ${ }^{44}$.

Prawa i obowiązki duchownych w Stowarzyszeniu kleryckim korespondują $\mathrm{z}$ ich funkcją, miejscem inkardynowania, z pełnionymi przez nich urzędami i zadaniami. Wszyscy żyją według charyzmatu,

\footnotetext{
${ }^{43}$ Por. Statuto, n. 7-12; M. Delgado Galindo, Movimenti..., dz. cyt., s. 663-664. ${ }^{44}$ Statuto, n. 13-15.
} 
który kultywuje adorację Najświętszego Sakramentu, codzienną Eucharystię, liturgię godzin i wspólnotę życia. Są oni też dyspozycyjni do zadań ewangelizacyjnych podejmowanych przez Wspólnotę, uczestniczą w spotkaniach Fraterni Jezusa, wspierają także finansowo dzieło sumą dobrowolnie określoną ${ }^{45}$.

Statuty Stowarzyszenia kleryckiego w artykułach 27-31 regulują sprawy związane z formacją. Dla tych, którzy będą inkardynowani do stowarzyszenia, odbywa się ona według norm aprobowanych przez Kongregację ds. Duchowieństwa i według Ratio samego stowarzyszenia. Z tych 'domków’ formacji mogą także korzystać ci, którzy będą inkardynowani do diecezji, a dzieje się to w porozumieniu między Odpowiedzialnym a poszczególnymi biskupami diecezjalnymi. Odpowiedzialnym za formację jest duchowny mianowany przez Kongregację, która też czuwa nad całością kształtowania duchownych. Diakoni stali odbywają formację specjalną według norm zatwierdzonych przez wspomnianą Kongregację Duchowieństwa i także Kongregację Edukacji Katolickiej oraz norm diecezji, gdy są do niej inkardynowani, i w duchu charyzmy Wspólnoty Emmanuel. Statuty w przedmiocie formacji przewidują również Delegata do spraw formacji, który jest członkiem Rady Międzynarodowej Wspólnoty. Ma on kontakt $\mathrm{z}$ rektorami poszczególnych 'domków' formacyjnych i koordynuje formację uwzględniając aspekty ludzkie, duchowe, intelektualne i pastoralne kandydatów ${ }^{46}$.

W przypadkach dobrowolnego opuszczenia Stowarzyszenia kleryckiego członek traci prawa i obowiązki związane ze Stowarzyszeniem, ale też członkostwo we Wspólnocie Emmanuel. W przypadku odejścia ze Stowarzyszenia kleryckiego duchownego inkardynowanego do diecezji pozostaje on dalej w niej inkardynowany. Natomiast gdy sprawa dotyczy duchownego inkardynowanego do stowarzyszenia, przed odejściem winien on szukać biskupa, który zechce go przyjąć na stałe do diecezji, albo na jakąś próbę. W przypadku znalezienia biskupa, Odpowiedzialny za duchownych w stowarzyszeniu przygotuje licencję

\footnotetext{
${ }^{45}$ Tamże, n. 16; por. M. Delgado Galindo, Movimenti..., dz. cyt., s. 662-665.

${ }^{46}$ Por. M. Delgado Galindo, Movimenti..., dz. cyt., s. 667-668.
} 
na ekskardynację. Natomiast gdy duchowny nie znajdzie życzliwego biskupa, pozostaje on inkardynowany do stowarzyszenia, jednak bez możliwości realizacji zadań pastoralnych w imieniu Wspólnoty. W przypadku seminarzystów i kandydatów do diakonatu stałego dobrowolne odejście ze Stowarzyszenia kleryckiego nie narusza ich przynależności do Wspólnoty.

W sytuacji zaistnienia przestępstw dokonanych przez duchownych lub innych trudnych przypadków Odpowiedzialny za duchownych w Stowarzyszeniu kleryckim powinien ich dymisjonować. Dekret dymisyjny musi być potwierdzony przez Kongregację ds. Duchowieństwa. Wydalenie jakiegoś członka Stowarzyszenia kleryckiego pozbawia go praw we Wspólnocie. Jeśli wydalony duchowny jest inkardynowany do diecezji, jego wydalenie ze Stowarzyszenia kleryckiego nie ma skutków w odniesieniu do inkardynacji. Natomiast, jeśli duchowny jest inkardynowany do Stowarzyszenia kleryckiego, on dalej pozostaje inkardynowany w stowarzyszeniu dopóki nie znajdzie przychylnego ordynariusza ${ }^{47}$. To są najistotniejsze rozwiązania prawne statutu Stowarzyszenia kleryckiego w kontekście inkardynacji duchownych i one rzucają światło na problem inkardynacji w 'ruchach kościelnych' w ogólności.

\section{Wokół uprawnienia inkardynacji w 'ruchach kościelnych'48}

Wśród zagadnień trudnych w kontekście 'ruchów kościelnych' wymienia się inkardynację duchownych. Problem ten narasta wraz

\footnotetext{
${ }^{47}$ Por. Statuto, n. 37-38.

${ }^{48}$ Jan Paweł II dał następujący opis 'ruchu kościelnego’: „Che cosa si intende oggi per 'movimento'? Il termine viene spesso riferito a realtà diverse fra loro, a volte, persino per configurazione canonica. Se, da un lato, esso non può certamente esaurire né fissare la ricchezza delle forme suscitate dalla creatività vivificante dello Spirito di Cristo, dall'altro sta però ad indicare una concreta realtà ecclesiale a partecipazione prevalentemente laicale, un itinerario di fede e di testimonianza cristiana che fonda il proprio metodo pedagogico su un carisma preciso donata alla persona del fondatore in circostanze e modi determinati”. Giovanni PAOLO II, Messaggio, 27 maggio 1998, nr 4, w: I movimenti nella Chiesa. Atti del Congresso mondiale dei movimenti ecclesiali, Roma 27-29 maggio 1998, Città del Vaticano
} 
z ilością i różnorodnością publicznych stowarzyszeń wiernych. Statystyki kościelne pokazują nie tylko ich ilość, lecz także pozytywny wpływ na wspólnotę Kościoła powszechnego i partykularnego. Co do ich ilości i różnorodności wystarczy wziąć do ręki statystyki przygotowane przez kompetentne dykasteria , by o tym się przekonać ${ }^{49}$. Problematyka ruchów kościelnych w swojej złożoności rodzi w interesującym nas kontekście inkardynacji bardzo wiele pytań. Jedno z nich, jak to już zostało zasygnalizowane we wstępie artykułu, może brzmieć: czy jest roztropnością $\mathrm{w}$ aktualnym stanie prawnym dawać upoważnienie do inkardynacji 'ruchom kościelnym'? Inne pytania są takie np.: skoro instytuty zakonne i stowarzyszenia życia apostolskiego mają prawo inkardynacji duchownych, to dlaczego nie mogą mieć takiego prawa 'ruchy kościelne'? Jeżeli w 'ruchach kościelnych' rodzą się powołania kapłańskie, to dlaczego nie udzielić im prawa inkardynacji? Dlaczego Kodeks Kościoła łacińskiego nie pozwala na inkardynację w tych 'ruchach kościelnych', a Kodeks Kanonów Kościołów Wschodnich pozwala na to niektórym stowarzyszeniom wiernych? ${ }^{50}$ Te pytania już też zostały postawione w mojej publikacji w roku 2013 i na nie było trudno odpowiedzieć ${ }^{51}$. Natomiast teraz, gdy są dostępne statuty Kleryckiego Stowarzyszenia Wspólnoty Emmanuel oraz gdy jest Nota Kongregacji ds. Duchowieństwa, o której

1999, s. 18. Por. także inne publikacje: M. Rivella, Verso una applicazione più aperta del principio dell'incardinazione?, Quaderni di diritto ecclesiale 15(2002), s. 160-167; L. Navvaro, L'incardinazione nei movimento ecclesiali?, Problemi e prospettive, w: L'istituti dell'incardinazione,. Natura e prospettive, a cura di L. Navarro, Milano 2006, s. 217-260; C. Mezzogori, Vocazione sacerdotale e incardinazione nei movimento ecclesiali: una questione aperta, Roma 2012; F. CocCOPALMERIO, Il problema della incardinazione dei chierici nelle associazione di fedeli, w: AA.VV., Studi in onore di Carlo Gullo, vol. I, Cittá del Vaticano 2017, s. 45-54.

${ }^{49} \mathrm{~W}$ publikacji tej jest krótki opis stowarzyszenia i także ewentualna jego zależność od Papieskiej Rady. Por. także, Associazioni internazionali di fedeli. Repertorio, Città del Vaticano 2004; por. także L. Martinez Sistach, Las asociaciones de fieles, Barcelona 2005; F. GonzÀles Fernàndez, I movimenti. Dalla Chiesa degli apostoli a oggi, Milano 2000.

${ }^{50}$ Por. CCEO, can. 579.

${ }^{51}$ Por. H. Stawniak, Inkardynacja..., dz. cyt., s. 14-15. 
poniżej, to można dostrzec wyraźnie troskę o inne Kościoły wpisaną w inkardynację i dopatrywać się jej sensowności w publicznych Stowarzyszeniach kleryckich.

Aby odpowiedzieć na wyartykułowane wątpliwości, warto przywołać wytyczne i kryteria, które bierze pod uwagę Kongregacja ds. Duchowieństwa, zanim udzieli uprawnienia do inkardynacji w publicznych stowarzyszeniach wiernych. Zostały one przyjęte na sesji Plenarnej Kongregacji ds. Duchowieństwa w dniach 30.05-1.06.2017 roku ${ }^{52}$. Oto one:

1. Winna być już dość duża liczba osób duchownych, aby zagwarantować rzeczywistą nowość i osobliwość charyzmatu kościelnego, z którego narodziło się Stowarzyszenie, aby uniknąć tworzenia „małych grup” duchownych, którzy po prostu dążą do „wyzwolenia się” spod władzy swojego ordynariusza dla realizacji osobistych projektów, a nie celów kościelnych.

2. Winna być możliwość zaoferowania wstępnej i stałej formacji, a także wsparcia materialnego dla duchownych na wypadek choroby i starości. W rzeczywistości dotyczy to duchownych inkardynowanych do stowarzyszenia i z tym się wiąże szereg obowiązków wobec nich. Są to obowiązki co do formacji początkowej i stałej (por. kan. 279 CIC), które muszą być im gwarantowane jako szansa na osobisty rozwój i świętość, ale także jako przygotowanie do bardziej owocnego wykonywania posługi. Warto pamiętać, że seminaria / domy formacyjne Stowarzyszenia z uprawnieniem inkardynowania muszą uwzględniać model pasterzowania zaproponowany przez Kościół powszechny. Formacja seminarzystów musi uwzględniać Ratio formationis, napisane zgodnie z Ratio fundamentalis institutionis sacerdotalis i zatwierdzone przez Kongregację ds. Duchowieństwa. W rzeczywistości, nawet jeśli istnieją różne charyzmaty, to istnieje tylko jedna służba

${ }^{52}$ La Nota della Congregazione per il Clero, którą można znaleźć: http://www. clerus.va/content(...)clerus/Plenaria\%202017-\%20Incardinazione.pdf [dostęp 30.11.2018]. 
kapłana powołanego, aby był pasterzem, sługą, ojcem i bratem dla ludu jemu powierzonego. Obowiązki Stowarzyszenia wobec duchownych są również natury ekonomicznej (por. kan. 281, $\$ \$ 1-2)$, dotyczą ich sprawiedliwego utrzymania przy sprawowaniu posługi i zabezpieczenia społecznego w przypadku choroby lub starości. Dlatego konieczne jest, aby Stowarzyszenie inkardynujące duchownych było solidną rzeczywistością duchową, a także z odpowiednim zapleczem ekonomicznym. Można tak powiedzieć, że Stowarzyszenie musi dysponować odpowiednimi narzędziami - formacyjnymi i ekonomicznymi - dążyć do celu, dla którego został erygowane i dla którego prosi o możliwość inkardynowania duchownych.

3. Stowarzyszenie winno być „dojrzałe” eklezjalnie, zdefiniowane i sprawdzone w czasie. Inkardynacja duchownych ma być owocem doświadczenia kościelnego w czasie, przez który stowarzyszenie może i musi wykazać wewnętrzną solidność i spójność, lojalność wobec Magisterium, użyteczność eklezjalną, zdolność do wytrwałości w wykonywaniu powierzonych prac złączonych z charyzmatem, dyspozycyjność do współpracy z diecezjalnymi biskupami w wykonywaniu posługi i opieki Ludu Bożego, w tym sensie musi być otwarte na współpracę.

4. Muszą być gwarancje dotyczące ludzkiego, duchowego i moralnego profilu Założyciela . Założyciele nowych rzeczywistości są charyzmatycznymi ludźmi, zdolnymi do przyciągania pewnej liczby wiernych, ale nie zawsze. Dlatego przed powierzeniem jednej z tych nowych rzeczywistości, czyli inkardynacji duchownych, jest niezbędne sprawdzenie - w miarę możliwości - czy Założyciel jest w stanie stawić czoło odpowiedzialności za wszystkie punkty życia duchownych wynikające $z$ inkardynacji.

5. Statuty gwarantują uzasadnioną autonomię zarządzania i wykonywania posługi w odniesieniu do szerszej rzeczywistości stowarzyszeniowej w ruchach kościelnych. W niektórych przypadkach Stowarzyszenie zamierza inkardynować 
duchownych, włączać osoby świeckie i konsekrowane i chce być kierowane przez osobę świecką. W takich przypadkach Kongregacja ds. Duchowieństwa, przed zatwierdzeniem statutu, sprawdzi, czy gwarantuje się, że Stowarzyszenie kleryckie będzie kierowane przez duchownego i, w zależności od niego, seminarzyści i prezbiterzy inkardynowani mogą otrzymać wskazówki dotyczące formacji i wykonywania posługi, ciesząc się tym samym niezbędną autonomią zarządzania w odniesieniu do osób świeckich, które uczestniczą w tym samym charyzmacie.

W świetle przedstawionych tych pięciu punktów o kryteriach można ocenić możliwość przyznania lub nie prawa inkardynacji. Natomiast Kongregacja ds. Duchowieństwa uważa, że uprawnienie inkardynacji w Stowarzyszeniach kleryckich, publicznych, na prawie papieskim może stanowić innowacyjny instrument (nie „nowy”, ponieważ był obecny w pracach przygotowawczych do CIC z 1983 r.) do regulacji istniejących lub bieżących rzeczywistości. Z drugiej strony, po zidentyfikowaniu i przygotowaniu instrumentu - taki jak opisany dotychczas typ inkardynacji - nie oznacza, że należy go używać w razie potrzeby. Inkardynacja duchownych bowiem rodzi różne i ważne konsekwencje teologiczne, kanoniczne, ludzkie, i dlatego musi być dobrze przemyślana w każdym przypadku i bez uogólnienia.

Erygowanie publicznego Stowarzyszenia kleryckiego, w ramach Wspólnoty Emmanuel przez Kongregację ds. Duchownych w 2017 roku pokazuje też ewolucję instytucji inkardynacji w 'ruchach kościelnych'. Poszczególni papieże udzielali papieskiego pozwolenia na takie rozwiązania prawne, które uwzględniałyby współczesne charyzmaty, misję ewangelizacyjną i przy uszanowaniu prastarej instytucji inkardynacji duchownych. Zatwierdzanie niektórych statutów ad experimentum $\mathrm{z}$ możliwością inkardynacji było sprawdzaniem, jak możliwa i użyteczna będzie ta droga posługi ministerialnej duchownych. Pozytywne doświadczenia w tym względzie zaowocowały erygowaniem Stowarzyszenia, które było przedmiotem rzetelnej analizy, jak się wydaje. Statuty uwzględniły złożoność sytuacji duchownych inkardynowanych do stowarzyszenia i tych stowarzyszonych 
a przynależących do diecezji. Nadto podkreśla się, że wszyscy duchowni inkardynowani w Stowarzyszenie kleryckie są prezbiterami świeckimi i wszyscy duchowni są członkami Wspólnoty lub Fraterni Jezusa. Chociaż Wspólnota i Stowarzyszenie kleryckie są odrębne, to jednak łączy je ten sam charyzmat i misja ewangelizacyjna. Z kolei Odpowiedzialny za duchownych w stowarzyszeniu kleryckim musi mieć staż przynajmniej 10 lat kapłaństwa i także 10 lat przynależności do Fraterni Jezusa ${ }^{53}$. Można zatem powiedzieć, że statuty Stowarzyszenia szczegółowo określają zarówno prawa i obowiązki duchownych, jak i kierujących osobą prawną. Wydaje się, że są one też dość przejrzyste w powiązaniu ze statutami Wspólnoty Emmanuel.

Należy dopowiedzieć, że Ojciec Święty Franciszek przyjął na audiencji członków Communauté de l'Emmanuel, z okazji ich dorocznego spotkania, które odbyło się w Rzymie. W dniu 7.04.2018 roku Papież przekazał osobom obecnym na audiencji między innymi słowa uznania i otuchy na przyszłość: „Ta przyszłość jest naznaczona niedawnym uznaniem Stowarzyszenia Kleryckiego Wspólnoty Emmanuel, 15 sierpnia, struktury nadającej się z powodu licznych powołań kapłańskich, które budzi charyzmat Emmanuela i większej owocności ewangelizacji. Daleko od izolowania kapłanów od innych członków wspólnoty, świeckich lub konsekrowanych, mam nadzieję, że to uznanie, przeciwnie, ożywi piękną komunię między stanami życia, których doświadczacie od ponad 40 lat, w komplementarności różnych powołań. Zachęcam również wasze wspólnoty do utrzymywania coraz ściślejszej więzi z bogatą rzeczywistością parafii, w której żyją, oraz do dobrowolnej integracji w organicznej opiece duszpasterskiej Kościoła partykularnego (por. Adhortacja apostolska Evangelii Gaudium , 29)"54.

\footnotetext{
${ }^{53}$ Por. M. Delgado Galino, Movimenti..., s. 671-672.

${ }^{54}$ https://press.vatican.va/content/salastampa/it/bollettino/pubblico/2018/04/07 /0253/00551.html [dostęp 11.12.2018]
} 


\section{Zakończenie}

$\mathrm{W}$ odpowiedzi na sformułowane pytania jawi się najpierw taka myśl, że byłoby niedopuszczalnym, jako sprzeczne $\mathrm{z}$ duchem soborowym i sensem inkardynacji, przyznać uprawnienia do inkardynacji duchownych każdemu publicznemu stowarzyszeniu wiernych. W tej sytuacji liczne skutki inkardynacji byłyby bowiem pod znakiem zapytania, zarówno po stronie inkardynującego, jak i inkardynowanego. Natomiast regulacja wyrażona w statutach Stowarzyszenia kleryckiego Wspólnoty Emmanuel uwzględniła zarówno pozytywne wpływy nowych 'ruchów kościelnych' na promocję powołania kapłańskiego i ewangelizację, jak i zabezpiecza prawa i obowiązki duchownych inkardynowanych. Kanoniczne regulacje są dobrze ukształtowane, gdyż nie gubią sensu i celu prastarej instytucji inkardynacji. Statuty nadto uwzględniły możliwość współpracy w misji Kościoła różnych stanów i grup ewangelizacyjnych oraz pokazały Wspólnotę Emanuel jako protagonistów „wychodzącego Kościoła”"

\section{THE CLERICAL ASSOCIATION OF THE EMMANUEL COMMUNITY WITH INCARDINATION AUTHORIZATION}

The article shows how the International Clerical Association of the Emmanuel Community, which in 2017 received the power of incardination, puts itself in the clergy's concern for all Churches and how the ancient institution in its evolution becomes an instrument of evangelization of contemporary challenges. The clerical association is seen as a phenomenon of clergy's connection with laity or consecrated persons in the Emmanuel Community, which enlivens beautiful communion between the states of life and contributes to the greater fruitfulness of evangelization.

SŁOWA KLUCzowe: Wspólnota Emmanuel; międzynarodowe kleryckie stowarzyszenie; publiczne stowarzyszenia; inkardynacja; troska o Kościół powszechny

Keywords: Emmanuel Community; International Clerical Association; public associations; Incardination; concern for the universal Church

\footnotetext{
${ }^{55}$ Tamże.
} 
NOTA O AUTORZE:

Ks. PROF. DR HAB. HeNRY K STAWNiAK SDB - prof. zw. dr hab. nauk prawnych w zakresie prawa kanonicznego, kierownik Katedry Kanonicznego Prawa Małżeńskiego i Rodzinnego, dziekan Wydziału Prawa Kanonicznego UKSW. 